1st International Conference - Global Ethics - Key of Sustainability (GEKoS) | May 15th, 2020 | Bucharest, Romania

\title{
Ethics in Romanian Public Administration
}

\author{
Marius NITA \\ https://doi.org/10.18662/lumproc/gekos2020/31
}

How to cite: Nita, M. (2020). Ethics in Romanian Public Administration. In A. Grigorescu \& V. Radu (vol. ed.), Lumen Proceedings: Vol. 11. 1st International Conference Global Ethics - Key of Sustainability (GEKoS) (pp. 305-315). Iasi, Romania: LUMEN Publishing House.

https://doi.org/10.18662/lumproc/gekos2020/31 


\title{
Ethics in Romanian Public Administration
}

\author{
Marius NITA ${ }^{1}$
}

Abstract

Ordinary people sometimes make immoral actions. Often, the answer can be given by the lack of relevant knowledge. They simply do not know that by their action they violate a rule or a moral requirement. Unfortunately, this is not the most common situation. The morality deficit is not mainly caused by a lack of knowledge. If that were the case, the problem would be solved simply by accessing the information or attending a course. Often, when people don't do what they should do morally, the explanation lies in the lack of motivation rather than in that of knowledge. When we talk about organizations, fairness is the fundamental virtue of public administration in ethical ethics which argue that what is morally correct is a priority over what is right. The integrity, rightly, transparency, and accountability of public administrations are basic requirements for a public trust, as a keystone of good governance. As with any other professional activity, ethical behavior in the civil service is promoted both through legal rules and through ethical standards that underpin and, at the same time, go beyond the legal requirements. The paper presented is a study that established the real level of ethics in our public administration based on the results obtained through a focus some important central and local public organization. This identification and interpretation of the organizational ethical concept was made to emphasize its importance in establishing the role of applied ethics, in the development and performance of a public organization.

Keywords: moral; individual; ethics; ethical theories; ethical management; ethical organizations.

\footnotetext{
${ }^{1}$ Valahia University from Targoviste, Romania, meser.nita@yahoo.com

(C) The Authors, LUMEN Conference Center \& LUMEN Proceedings.

Selection and peer-review under responsibility of the Organizing Committee of the conference
} 


\section{Introduction}

The public good is considered by all leaders of public administration the defining ethical value of any administrative system [24]. The implementation of this value in a democratic administrative system, implies a series of other values including transparency, welfare, equity, public interest [18]. The public good becomes the public interest. Well-being plays a central role in the construction of any moral theory, but also in any public policy that has as a starting point the realization of ethical values [2]. In order to be able to speak truly of the public good, the decision on the political perspective must be of a collective in nature. Speaking of public ethics, we are talking about the ethical values of public servants and public institutions.

The institutionalization of ethics in public organizations in Romania is a process assumed by leaders, especially after joining to the European Union, as part of European policies. Efficiency, transparency, responsibility are ethical values accepted as mandatory in all European countries. In the democratic and legal state, the role of public administration is to translate the political vision of the majority party or parties into governance instruments - and thus into social order.

In this paper I will briefly argue the, the importance of a public administration focused on ethical values and I will examine the state of ethics implementation in public administration. The public good, along with justice, can be considered fundamental ethical values of any institution, and the values of equity, transparency, responsibility - as operational ethical values of contemporary public administration systems.

The main objectives of my study are to identify the difference between applied ethics theory and ethics in our public administration, thinking directions regarding the analyzed concept, their evolution, in relation with organizations from other country.

To achieve the objectives, the research methodology used in the development of this approach consists of: documentation, descriptive and explanatory analysis of the specialized literature, synthesis. The proposed research is theoretical, qualitative and tries to present the main ways of approaching and defining the concept of ethical public organization.

The purpose of this study is to present the multidimensionality of the organizational ethics concept by approaching it either from the perspective of the elements or values that make it up, or from its characteristics and functions, as they result from the level of institutionalization ethics in public institutions. 


\section{Problem Statement}

Defining the term ethics is difficult because we should explain many other words and terms or expressions [1]. Ethics is interested in both the person's character and his demeanor [3]. It addresses both personal and organizational issues or public policy issues. In the first sense, ethics is also defined as science that deals with those characteristics that people acquire through habit (gr. ethos = the usual way of life). Ethics is the set of rules based on the distinction between wrong and right. Moral is that set of rules of conduct provided with such a mechanism that their violation leads to the disapproval of a person or of an entire community towards the one who violates that rule [7]. In a second sense, ethics is the intersection between lows, behavior and individual phenomena [20]. To have ethical behavior is similar to always committing moral deeds, and moral norms show what they must or should not do [8], so that the results of the behavior manifested are appreciated as good or bad.

Three main ethical perspectives have been studied [19], as a conclusion of the search for criteria to differentiate between what matters and what doesn't really matter: virtue ethics, deontological ethics, utilitarian ethics.

Figure no. 2 Ethics types

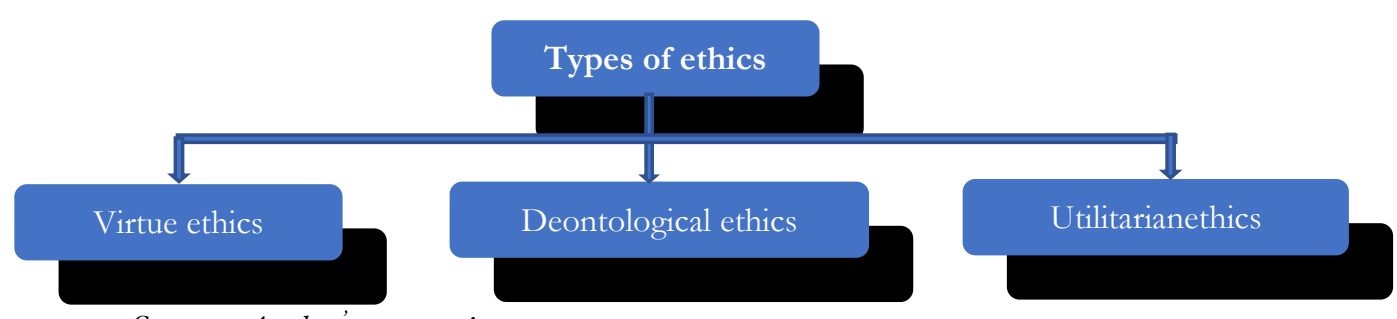

Source: Author's conception

\section{A. Virtue ethics}

The ethical theories of Antiquity consist in virtues, as skills or customs. Ancient philosophers believed that virtues were achieved during the life from families, schools and society, not through study [5]. A reasonable life based on the realization and practice of virtues is the way of forming a good character [25]. The virtues of ethical theory do not emphasize the rules that a person should follow but focus on helping people develop good character, such as honesty and generosity [16]. 


\section{B. Deontological ethics}

Deontological ethics start with Kant and Hegel. Kant thinks that moral law is the individual obligation. In this sense, Kant proposes to us a principle of universalization: act so that what you want to do can become a universal law for all people and, perhaps in addition, a principle of humanity: act in such a way as to treat any person as yourself. In social interaction we must consider not only our personal goals, but also the respect we owe to others as people with their own desires, needs and aspirations [26].

Kant's theories were taken over by W.D. Ross and later by T. Beauchamp and J. Childress [13], concerned that deontologists did not accept any exception to the principles. Thus, in their opinion, principles are not standards that do not accept compromise. They must be specified in such a way that they can operate in particular circumstances and often adapted to other moral norms, and in some circumstances, they can be justifiably violated because they are subject for different moral norms with which they are in conflict [15].

\section{Utilitarianethics}

Thinkers believe that an action is good or fair if it maximizes happiness (pleasure) and minimizes suffering (pain) for as many individuals as possible, and a right decision has the best consequences [16]. For utilitarians, unlike Aristotle, happiness means acquiring pleasure and avoiding suffering. They are based on the principle of greatest happiness: actions are correct when they produce happiness (Socaciu \& collective, 2018) [26]. Utilitarians believe, unlike Kant, that we must seek our happiness [5]. This goal becomes the ultimate moral duty to oneself, and facilitating the happiness of others is a moral duty [7].

The three ethical perspectives lead to different responses in many situations, especially when we have to choose between important values that are in conflict and cannot be achieved simultaneously [23]. The main questions asked in the three theories are distinct: virtue ethics asks us: what kind of man do I want to be, utilitarian ethics makes us reflect on the question: does action lead to the best condition and deontological ethics makes us reflect on the principles that must be respected as a fair action, towards others and towards ourselves: what are the basic fundamental principles that I respect?

Systemic analyzed, ethical theories can be theories of justice or good. The first approach refers to the right reason in relation with nature, and the second addresses the idea of promoting the positive consequences of action [14]. However, at a more careful analysis the first theory has a component of good too because we must fulfill our duty to do good to our fellow human 
beings. As a result, good is a common element regardless of ethical typology. Naturally, differences arise in terms of content and sources of each theory.

On the other hand, the ethics does not involve positive acts in themselves that are not useful to anyone, because it is based on social relations. Ethical conditions are obligations to do good to people [22]. Virtue ethics assumes that what is morally important is not so much to find the principle that guides our actions in each situation, that tells us, deductively, what debts we have (see deontological ethics) or how to make a certain moral calculation (see utilitarianism), but it is important to end up having a moral character, that is, to be virtuous [11]. This does not mean that the idea of virtue does not play an important role in utilitarianism and deontological. The development of a moral (virtuous) character is a necessary condition to achieve the state of well-being, and the observance of rules, which limits the pursuit of one's own interests, will be that achieved by a virtuous man [17].

\section{Research Questions/Aims of the research}

There is a strong effective relation between ethic and good administration of any organization. Each organization is personalized by the way of expressing its own personality, personality created by the people who make it [4]. Their relationships within the organization or in interaction with the environment lead to the establishment of a complex network of ethic meanings defining an organizational lifestyle structured on certain values, beliefs and morals [21].

Unfortunately, there are few organizations that take ethical programs seriously today [9]. These programs would, moreover, be quite complicated, encompassing uncomfortable tasks that pass as redundant in the eyes of the ordinary manager, focused only on profit [12]. There are no other moral regulations. In these conditions, it would be surprising to have means of implementing the code of ethics [6].

The literature presents us several approaches with the characteristics and elements that define an organization as ethical: the manager of the organization, ethical committees, ethical codes, ombudsperson, ethical decision-making methods, ethical training, ethical auditing [16]. 
Figure no. 2 Institutionalization of ethics

Source: Author's conception

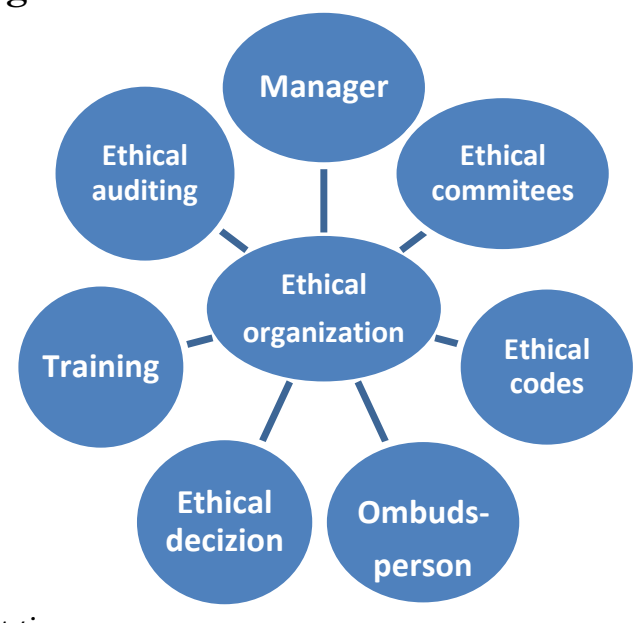

The purpose of the study is to analyze the level of implementation ethics in romanian public administration, as a part of our integration in European Union, in fact, to promote citizens' trust in the public service and the institutions it serves.

\section{Research Methods}

Having collected preliminary information through dialogs with employers from public administration and open sources, I studied regulations, contacted both managers and employers, in order to confirm some information, they had provided me. Examining internal documentation, email exchanges and manuals, I managed information in order to obtain relevant information and ensure construct validity. Based on observations, study and analyze, I identified the level of ethics in our public administration. Such analysis provided me with a good understanding of the observations, and offered empirical evidence of the links and relationships between real level of ethics in our public institutions.

\section{Findings}

In Romania, things are different when it comes to administration, as central or local public institutions are subject to complex and abstract legislation regarding the institutionalization of ethics [10]. 
Central public institutions have issued domain-specific codes of ethics, and at the local level, organizations have customized these codes, taking into account the peculiarities of the legal framework of organization and operation. At the level of each public entity, ethics is part of the internal management control (standard 1 - Ethics and integrity), the manager have the responsibility of operationalize.

I try to analysis on the state of ethics in public administration and find that the expression ethics management is missing from the legislation and as a result it is rather unknown among managers or staff responsible with the implementation of ethics. Referring to managers, ethics tasks are in general delegated, they are not a priority. Ethical committees are rather bureaucratic structures and they exist only on paper, the staff having no qualifications in this regard. With few exceptions, there are no ethics committees by professions, which hold the state of national authority, and where they are, they work hard and inefficiently (e.g. the College of Physicians of Romania). Ethical committees at the institution level are in the same situation. Ethical training does not exist and therefore ethical committees practice more arbitration than ethical decisions made on the basis of systemic moral judgment procedures. They also cannot perform their ethical advice function to clarify the moral issues that arise within the organization.

In general, ethical codes exist, but having an ethical code is not enough. In order to make an ethical code necessary, complex implementation measures and development programmers are needed with the evolution of the organization and the periodic challenges that arise. I appreciate that still, at the managerial level, they are not aware of its importance, it is not understood that through these codes of ethical conduct high standards of professional can be institutionalized and promoted high standards of professional behavior in the activities of the institution.

The ombudsperson is the person responsible for the institutionalizing of moral values in the organization, but also for solving moral disputes, does not exist in the legislation and implicitly neither in the life of a public entity. At the national level, we have the ombudsman, a person responsible for protect the rights and freedoms of citizens in their relations with public authorities. In fact, we talk about a politician, part of political dispute, not a person known for its judicial jurisdiction and exemplary probity [18].

Regarding to ethical decisions, after a simple analysis of the public environment in Romania, it can be observed that they are almost entirely missing from the entire process of ethical management of a public organization. If I asked an official the question: after what method you solve 
ethical problem in your organization; the answer will most likely be by professional competence, experience and moral norms. Very few people will invoke an ethical decision method. Officials who work in the domain know that ethical decisions are not a simple matter, that they cannot be based solely on traditions or common sense. Complex cases involve professional competence and experience, starting with identifying the ethical dimension of the case, continuing with a framework of moral evaluation (utilitarian, deontologist or virtue ethics) and ending with a decision in compliance with the pluralism of moral values and ethical methods. Of course, professional competence and experience are very important, but not enough to make ethical decisions.

The training, also does not exist as a concept in legislation and implicitly neither in the work of a public, central or local entity. As a result, the persons with responsibilities in ethical management processes do not have the necessary ethical knowledge and at the level of employees, their lack of skills will be felt and, perhaps most importantly, their decisionmaking capacity in the ethics domain. For example, the U.S. adopted in 1991 a law that requires organizations to develop ethical training programs to detect and prevent violations of laws (The US Sentencing Guidelines for Organizations), and the amount spent for this purpose by government bodies at all levels exceeds a billion dollars.

Ethical audit, as a systematic activity that carries out a radiography of the various relevant aspects of the ethics of an organization is another concept that is missing from the legislation and implicitly from the processes of ethical management in public institutions in Romania. There is no line phone dedicated to ethical complains, it is not desired in most cases, although many employers recognize the existence of claims with moral content. But there are no moral activities and moral consultants, as there are no ethical audit activities. The vast majority do not see any link between ethical criteria and the strategic plan, almost all of them are fixed on the Christian ethics as the sole paradigm of moral evaluation.

Starting from the common legislative norms, at central level, through the representative bodies at ministerial or departmental level, were created codes of ethics specific to each domain, and further, at local level, each structure customized this code. Even if they differ from one structure to another, they also have some common elements: legality, professionalism, honor, moral integrity, patriotism, transparency. 


\section{Discussions}

In the public administration, ethics seek to address the essential issues relating to the civil servants' duty to act in the service of people, of the public interest. This refers to the core values which should guide the judgment and the act of public servants in the performance of their daily tasks and in their relations with the public. If the actions of the civil service are doing with ethics principles this must contribute to the realization of public power. And power public administration involves public trust. Citizens expect public servants to serve the public interest, to manage public issues properly on a daily basis, and to make individual decisions truly and justly. Reliable public services and predictable decision-making inspire public trust.

\section{Conclusions and Further Developments}

Trust depends upon a belief in the integrity of leaders and in the same measure, officials or simple employers who are expected to conduct themselves in a manner that will bear the closest possible control. Of course, this obligation is not fully discharged just by acting within the law, trust also requires that public employers make recommendations and decisions only with an eye to serving only the public interest. Nothing erodes trust and confidence faster than unethical conduct. The importance of ethical principles with virtues and values that define and underpin a well-constituted modern public service cannot be direct overstated. In a democracy, it is fundamental, firstly to provide both public officials and the public at large with a common frame of reference regarding the principles and standards to be applied and secondly to assist public officials to develop an appreciation of the ethical issues involved in effective and efficient public service delivery.

However, if we refer to any of the theories of the ethical organization, we see that there are still many steps to be taken in this regard, in order to obtain an ethical organization in the true sense of the word in the Romanian public administration. Countries with a rich tradition (the U.S., Japan), have laws on morality in public administrations, which means to creation a Committee on Ethics at national administration, the creation of their supervisors on ethical issues in all ministries and agencies, an ethical code for civil servants has been issued and ethical management has been introduced in local administration. But the resistance to ethical institutionalization is strong and it sometimes takes forms that hide the true grounds. 
It is clear that in Romania organizations in general and public institutions in particular do not excel in this chapter, compared to the situation in countries such as the Netherlands, Denmark, Sweden, Japan or the United States, but recent research and studies also show in Romania steps to institutionalize ethics. There can be noted, for example, the studies of the Applied Ethics Research Center (CCEA) of the Faculty of Philosophy, the University of Bucharest, the research carried out by Transparency International Romania in 2011, and, more recently, the research of the Legal Resource Center in 2013. Even if they are at the beginning, they can still initiate the opening of organizations in Romania for the institutionalization of ethics, the important thing is the awareness of the managers organizations about the advantages brought in the smooth running of the activities. In addition, the legislation in this area is also beginning to take steps in this regard, and they need to understand that there is still a long way to go before alignment with the European Union legislation.

\section{References}

[1] Capcelea V. Etica şi conduita umană; Chişinău: Editura Arc; 2010.

[2] Casapu MT. Etica şi morală profesională, 2020. Available from: https://blog.avocatoo.ro/etica-morala-si-etica-profesionala/

[3] Cătineanu T. Elemente de etică. Vol. 1. Cluj-Napoca: Editura Dacia, ClujNapoca; 1982

[4] Crăciun D. Etica în afaceri. Bucureşti: Editura A.S.E; 2005.

[5] Constantinescu M, Mureşan V. Instituționalizarea eticii. Bucureşti: Editura Universității; 2013.

[6] Cooper, TL. The responsible administrator. Sixth edition, Los Angeles; 2011.

[7] Cozma, C. Etică - Suport de curs. Iaşi: Universitatea Tehnică „Gheorghe Asachi”; 2018.

[8] Georgescu M-A. Etica între teorie şi acțiune. Târgu Mureş: Editura Universității Petru Maior; 2011.

[9] Grigorescu A. Quality and customer satisfaction in public services. Amfiteatru Economic. Bucureşti: Academia de Studii Economice; 2008.

[10] Grigorescu A, Bob C. Discriminant analysis for the abilities of public marketing specialists. Regulation and Best Practices in Public and Nonprofit Marketing; 2010.

[11] Iamandi I-E. Etică şi responsabilitate socială corporativă în afacerile internaţionale. 2012. Bucureşti: Academia de Studii Economice.

[12] Kaptein, M. Ethics Management. Auditing and Developing the Ethical Content of Organizations. 1998, p. $47-60,146-173$.

[13] Knapp SJ, Gottlieb MC, Handelsman MM. Dileme etice în psihoterapie. Bucureşti: Editura Trei; 2016. 
[14] Matei A. Organizarea administrației centrale de stat: politici şi instrumente; Bucureşti: Editura: SIGMA/OECD şi NISPAcee; 2007.

[15] Menzel D. Ethics Management for Public Administrators. Sharpe, London; 2007.

[16] Mureşan V. Managementul eticii în organizaţii. 2009. Bucureşti: Editura Universității..

[17] Mac Namara C. Complete Guide to Ethics Management: An Ethics Toolkit for Managers Complete Guide to Ethics Management: an ethics toolkit for managers; 2009.

[18] O'Reilly E. Ensuring ethics in public administration: The role of the Ombudsman; 2012. Available from:. https://www.ombudsman.europa.eu/ro/speech/en/49379.

[19] Papanikitas A, Spicer J. Handbook of Primary Care Ethics. London: CRC Press; 2018.

[20] Pleşu A. Minima Moralia. Bucureşti: Editura Humanitas; 2013.

[21] Popa M. Etica afacerilor şi managementul. Cluj-Napoca: Editura Casa Cărții de Ştiință; 2006.

[22] Preda M. Comportament organizațional. Editura Polirom; 2006

[23] Provis C. Ethics and Issues in Public Policy. Policy and Society. 2007; 26(3): 21-33.

[24] Sandu A. Etică profesională şi transparenţă în administraţia publică. București: Editura Didactica si Pedagogica; 2015.

[25] Singer P. Tratat de etică. Bucureşti: Editura Polirom, Socaciu, E. \& colectiv. Etică şi integritate academică. Bucureşti: editura Univ. Bucureşti; 2018.

[26] Țigu G. Etica afacerilor în turism. Bucureşti: Editura Uranus; 2003. 